\title{
Community Perception on Breed Selection and Feeding Practice among Small Holder Dairy Farmers in Tiyo District, Arsi Zone, Ethiopia
}

\author{
Dereje Girma, Tajeb Jerjero and Solomon Mekuria* \\ Hawassa University School of Veterinary Medicine, Hawassa, Ethiopia
}

\begin{abstract}
A cross-sectional questionnaire survey carried out at Tiyo district of Arsi zone from October 2015 up to April 2016. The objective of study includes assessing smallholder dairy farm reproductive performance and associated production problems. Data collected from selected four kebeles; in two agro-ecological zones namely, Dega and Woina Dega. Questionnaires subjected for two groups of household who own local and cross breeds. 384 informants who have at least one local or cross breed cow included in selection. Among the informants $65 \%$ of them have attended elementary school and followed by $15 \%$ illiterate and the remaining were diploma and degree holders. Local breeds kept by less educated farmers than educated ones. Feeding practice depends on season and learning status, where feeding practice significantly different $(p<0.05)$ between wet and dry season, and in higher educated groups, they use more concentrate feed regardless of the season. The overall average daily milk yield per cow, lactation length and calving interval of local breeds were $1.06 \pm 0.65$ liter, $10.29 \pm 2.28$ months and $3.1 \pm 0$ years, respectively. Whereas, cross breeds had $6.49 \pm 1.65$ liters, $16.79 \pm 2.83$ months and $2.63 \pm 0.43$ years, respectively. The difference in parameters were significant $(p<0.05)$ between local and cross breeds. Butter and cheese mostly supplied to local markets by local breed owners, whereas whole milk marketing well experienced by cross breeders. This may be associated with better milk production in cross breeders. On the other hand, informants have mentioned the problem of abortion, delay in first calving, long calving interval, mastitis and retained fetal membrane with the prevalence of $11.49 \%, 7.8 \%, 20.3 \%, 9.9 \%, 2.08 \%$ and $0.26 \%$, respectively. In general, this study shown dairy cow management gap in the area. To reduce the problems noted, Al and veterinary services and forage and fodder development has to be improved. Awareness creation among farmers and stakeholders is also paramount important.
\end{abstract}

Keywords: Local; Cross breeds; Feeding practice; Education; Tiyo; Oromia; Ethiopia

\section{Introduction}

Cattle are an important livestock species in the traditional mixed crop- livestock production in Ethiopia by providing mainly drought power, milk, meat and manure. In dairy production cattle, camels, goats and sheep are the main livestock species that supply milk in the country, with cows making up $83.4 \%$ of the total annual milk of the country. The country's milk production level increased only by $1.6 \%$ and per capital production declined about $0.8 \%$ yearly during 1966-2001 [1].

Despite the presence of huge number of cattle population and favorable climate for livestock Production, current milk production is low. This is justified by low per capital milk production and increased import of milk and milk products. Like most developing countries, in Ethiopia there is an increase human population, urbanization and rising household incomes has become a driving force to increase livestock product demand, milk and Meat in particular. To meet the growing demand in Ethiopia milk production has to grow at least a rate of four percent yearly. Bridging the gap needs a suitable design and sustainable dairy development strategies; according to socio-economic, institutional and agro-ecological situation in the country $[2,3]$.

The traditional (smallholder) milk production dominated by indigenous breeds, which accounts about $97-98 \%$ of the total annual milk production in the country. Over $85 \%$ of the milk produced consumed by rural households themselves and the remaining marketed outside [4]. Most of milk produced outside urban centers in the country processed into milk products at household level using traditional technologies. There is little to none experience of whole milk sale to the market [5].

Productive and reproductive performance of cattle influenced by feed, genetics, disease and management practices. Feed and the nutritional quality of the available feeds are the most important reasons that determine the productivity of livestock. Livestock production throughout the world is dependent on various feed. The livestock production in Tigray region, as in many parts of Ethiopia, is traditional and dependent on crop residues, natural grazing and agro-industrial byproducts [2].

Understanding feed and its nutritional quality are important to improve milk production and therefore strengthen food security. It provides proper knowledge to dairy producers and smallholder farmers. Therefore, the result of this study can have important contributions to individuals or institutions working in dairy development as well as dairy policy makers. In addition, the study will add knowledge and can serve as a springboard for the future research, development work and policy decision.

Therefore, the objectives of the study were to assess smallholder dairy farm reproduction performance, the type of breed kept and their feeding experience to obtain the maximum product as well as to identify major problem associated with dairy farm management.

*Corresponding author: Solomon Mekuria, Hawassa University School of Veterinary Medicine, Hawassa, Ethiopia, Tel: 0911702366; E-mail: solmk2010@gmail.com

Received May 19, 2017; Accepted June 15, 2017; Published June 16, 2017

Citation: Girma D, Jerjero T, Mekuria S (2017) Community Perception on Breed Selection and Feeding Practice among Small Holder Dairy Farmers in Tiyo District, Arsi Zone, Ethiopia. J Vet Sci Technol 8: 451. doi: 10.4172/2157-7579.1000451

Copyright: @ 2017 Girma D, et al. This is an open-access article distributed under the terms of the Creative Commons Attribution License, which permits unrestricted use, distribution, and reproduction in any medium, provided the original author and source are credited. 


\section{Material and Methods}

\section{Study area}

The study conducted from October 2015 to April 2016 in Tiyo disrict. In Arsi zone, Oromia regional state about $175 \mathrm{~km}$ southeast of Addis Ababa at $6^{\circ} 59^{\prime}$ to $8^{\circ} 49^{\prime} \mathrm{N}$ latitudes and $38^{\circ} 41^{\prime}$ to $40^{\circ} 44^{\prime} \mathrm{E}$ longitudes. The altitude of the area ranges from 2500 to 3000 m.a.s.l. Tiyo district characterized by mid subtropical weather, with minimum and maximum temperature ranging from 8.4 to $22.6^{\circ} \mathrm{C}$ and the relative humidity ranging from 43 to $60 \%$. The average rainfall is $2000 \mathrm{~mm}$. The area has a bi modal rainfall, where short rainy season occur from March to April and long rainy season from July to October. Furthermore, according to Arsi Planning and Development Office, the area is densely populated, with livestock population of 85,893 cattle, 57,118 sheep, 10,725 goats, 7841 horses, 15,642 donkeys, 517 mules and 35,489 poultry. The farmers in the area practice mixed crop-livestock farming (personal observation).

\section{Study subject}

Farmers who own livestock, selected for questionnaire survey at different agro-ecological zone in Tiyo district. Equal opportunity has given to households who have kept local and cross breed dairy cows.

\section{Sample size determination}

A random sampling procedure employed to select sample kebeles and households for the study. The district first stratified as Dega (cold highland) and Woina Dega (midland) agro-ecologies. Out of 18 Kebeles in the district, 4 Kebeles randomly selected from each agro-ecology. The total number of informants required for the questionnaire survey determined based on the formula given by Trushfield for simple random sampling method [6].

$$
n=\frac{1.96^{2}\left(P_{\exp }\left(1-P_{e x p}\right)\right.}{d^{2}}
$$

Where $\mathrm{n}$ is the required sample size, Pexp is the expected prevalence and $\mathrm{d}$ is the desired absolute precision. Number of households was calculated by taking the expected prevalence of $50 \%$ due to lack of previous similar study in the area. Therefore, 384 households used for questionnaire survey.

\section{Study methodology}

A structured questionnaire survey conducted on 384 informants to collect the required information focused on the household characteristics; reproduction, milk production; animal feed; and common health problems encountered on their cows in the area.

\section{Data management and analysis}

The quantitative data collected entered into Microsoft Excel spread sheet and summarized using descriptive statistics. Associations between assumed factors were compared using STATA 9 software. Analysis considered being significant when p-value is less than 0.05 .

\section{Results}

\section{Educational background of the informants}

Among 384 interviewed those who had elementary educational background was dominant (65.36\%) followed by illiterate group (15.1\%) and while those degree holder farmers were the least $(2.08 \%)$. The remaining group falls in between as it was shown in Table 1.

\section{Breed types owned by informants}

Among the informants, who were illiterate and elementary school background had high proportion of local breed as compared to farmers who were high school, diploma and degree educational background. However, there was no significant difference $(\mathrm{p}>0.05)$ among farmers in selecting breed type. The proportion of Holstein cross and local breeds were almost equal throughout educational background as shown in Table 2 .

\section{Feeding style during wet and dry season according to educational status}

Main feed provision in the area were crop residue like teff, barley and wheat straw; communal grazing and concentrate supplement like oilseed cake, wheat bran were common practice in the area. However, feeding style varies according to the season and individual farmer's income capacity.

During wet season all farmers use natural grazing when compared to that of crop residue and concentrate feeding with significant difference $(p<0.05)$. They provide concentrate as supplement rather than as main source of feed in wet season. However, those degree holder farmers had no significant difference $(p>0.05)$ in feeding crop residue, natural grazing and concentrate. Furthermore, during dry season all informants responded that crop residue used as the main source of feed (100\%) followed by concentrate $(37.5 \%)$ and natural grazing $(5.7 \%)$ Feed provision had relatively different among farmers, where diploma and degree holders used more concentrate feed than natural grazing as shown in Table 3.

\section{Daily milk yield, lactation length, calving interval and AI service}

According to the informants average daily milk yield, lactation length and calving interval had significant difference $(\mathrm{p}<0.05)$ between local and cross breeds, where local breeds had low daily milk yield, short lactation length and long calving interval. On the other hand, AI service more practiced within cross breeds cows than local breeds. The overall

\begin{tabular}{|c|c|c|}
\hline Educational status & Number of informants & Proportion \\
\hline Illiterate & 58 & $15.1 \%$ \\
\hline Elementary & 251 & $65.36 \%$ \\
\hline High school & 54 & $14.06 \%$ \\
\hline Diploma & 13 & $3.36 \%$ \\
\hline Degree & 8 & $2.08 \%$ \\
\hline Total & 384 & $100 \%$ \\
\hline
\end{tabular}

Table 1: Educational background of the farmers involved in small holder dairy farm at Tiyo district

\begin{tabular}{|c|c|c|c|c|}
\hline $\begin{array}{c}\text { Educational back } \\
\text { ground }\end{array}$ & $\begin{array}{c}\text { Respondent } \\
\text { number }\end{array}$ & $\begin{array}{c}\text { Local } \\
\text { breed }\end{array}$ & $\begin{array}{c}\text { Cross } \\
\text { breed }\end{array}$ & P-value \\
\hline Illiterate & 58 & $28(48.3 \%)$ & $30(51.7 \%)$ & 0.99 \\
\hline Elementary & 251 & $128(51.0 \%)$ & $123(49 \%)$ & 0.85 \\
\hline High school & 54 & $34(63.0 \%)$ & $20(37.0 \%)$ & 0.11 \\
\hline Diploma & 13 & $4(30.8 \%)$ & $9(69.2 \%)$ & 0.50 \\
\hline Degree & 8 & $3(37.5 \%)$ & $5(62.5 \%)$ & 0.96 \\
\hline Total & 384 & $197(51.3 \%)$ & $187(48.7 \%)$ & 0.68 \\
\hline
\end{tabular}

Table 2: Educational background compared with breed types owned by the farmer 


\begin{tabular}{|c|c|c|c|c|c|c|c|c|c|}
\hline \multirow{2}{*}{ Education status } & \multirow{2}{*}{$\mathbf{n}$} & \multicolumn{4}{|c|}{ Wet season } & \multicolumn{4}{|c|}{ Dry season } \\
\hline & & Crop residue & Natural grazing & concentrate & P-value & Crop residue & Natural grazing & Concentrate & P-value \\
\hline Illiterate & 58 & $22(37.39 \%)$ & $58(100 \%)$ & $14(24.14 \%$ & 0.00 & $58(100 \%)$ & $7(12.07 \%)$ & $27(46.55 \%)$ & 0.00 \\
\hline Elementary & 251 & $42(16.7 \%)$ & $251(100 \%)$ & $23(9.2 \%)$ & 0.00 & $251(100 \%)$ & $12(4.78 \%)$ & $84(33.47 \%)$ & 0.00 \\
\hline High school & 54 & $25(46.29 \%)$ & $54(100 \%)$ & $8(14.81 \%$ & 0.00 & $54(100 \%)$ & $3(5.56 \%)$ & $15(27.78 \%)$ & 0.00 \\
\hline Diploma & 13 & $12(92.31 \%)$ & $6(46.16 \%)$ & $10(76.92 \%$ & 0.02 & $13(100 \%)$ & 0 & $12(92.31 \%)$ & 0.00 \\
\hline Degree & 8 & $8(100 \%)$ & $7(87.5 \%)$ & $7(87.5 \%)$ & 0.50 & $8(100 \%)$ & 0 & $6(95 \%)$ & 0.00 \\
\hline Total & 384 & $109(28.4)$ & $376(97.9)$ & $62(16.14)$ & 0.00 & $384(100 \%)$ & $22(5.7 \%)$ & $144(37.5 \%)$ & 0.00 \\
\hline
\end{tabular}

Table 3: Feed provisions for dairy cows in different season based on educational status.

\begin{tabular}{|c|c|c|c|c|c|}
\hline Breed & Number of informants & $\begin{array}{c}\text { Mean } \pm \text { SD } \\
\text { milk/day }\end{array}$ & $\begin{array}{c}\text { Mean } \pm \text { SD } \\
\text { LL (months) }\end{array}$ & $\begin{array}{c}\text { Mean } \pm \text { SD } \\
\text { Cl (years) }\end{array}$ & $3.1 \pm 0$ \\
\hline Local & 197 & $1.06 \pm 0.65$ & $10.29 \pm 2.82$ & $64(32.5 \%)$ \\
\hline Cross & 187 & $6.49 \pm 1.65$ & $16.79 \pm 2.83$ & $2.63 \pm 0$ \\
\hline Total & 384 & $3.70 \pm 2.99$ & $13.5 \pm 3.97$ & $2.8 \pm 0.43$ \\
\hline & p-value & 0.000 & 0.000 & 0.000 \\
\hline
\end{tabular}

Table 4: Daily milk yield, lactation length, calving interval and Al service in selected Kebele of Tiyo district.

mean daily milk production, lactation length and calving interval shows lower than acceptable level as shown in Table 4.

\section{Marketing practice of whole milk and milk products sale}

In this study who have local breed had poor experience in selling whole milk, except four informants $(2.3 \%)$, most of them $(69.0 \%)$ had good experience in selling milk products like butter and cheese. Among the informants who owned cross breed $118(63.1 \%)$ practiced whole milk selling, whereas $185(98.9 \%)$ and $184(98.39 \%)$ of them had the experience of selling butter and cheese, respectively. There are group of informants who have good experience in marketing both whole milk and milk products. Problems associated with selling practice as described as mainly scarcity of milk and lack of market as complained by local animal owners as shown in Table 5 .

\section{Major reproductive problems reported during questionnaire survey}

In the study area long calving interval $(20.31 \%)$ was the most common problem of the animal owners than other problems. Besides this, abortion (11.46\%), delay of first calving (7.81\%), mastitis $(9.89 \%)$, retained fetal membrane $(2.08 \%)$ and uterine prolapse $(0.26 \%)$ also mentioned as shown in Table 6.

\section{Discussion}

The educational level attain by most informants were low which falls between illiterate and primary school. As reported by Asaminew, low-level education can have a negative effect to develop dairy farm [7]. Less educated farmers experienced by poor usage of dairy technology such as artificial insemination, cultivation of improved forage crops and access to veterinary services. The percentage of illiteracy (15.1\%) in this study was lower than reported by Tesfaye in Metema (45\%) and Fisseha in the Bure district (50\%) [8,9]. As showed in the result, most of informants in the study area had attended certain education. The study shows education is growing in the area, which contributes for a better agricultural practices and wise usage of scarce agricultural resources. In addition, it is a good opportunity to facilitate extension services for rural development and transferring technology.

In Ethiopia, natural grazing and browsing fallow lands, Enset ventricosum and stubble grazing following the crop harvest was the major feed resources [10]. The major feed sources for dairy cattle in the study area include natural grazing, concentrate and crop residues. Most of the informants in the study area use combinations of different feed resources based on availability. Natural grazing had significantly utilized $(\mathrm{p}<0.05)$ compared with crop residue and concentrate during wet season because of rainy season in which grass was excessively available for their cattle. Degree holder informants used both crop residue and concentrate during wet season for their cow. This may be due to the absence of land so they keep indoor and supplement concentrate to have high milk production. The effort made to improve utilizing crop residues and cultivation of improved forage crops on private lands not practiced by many of the informant. The entire dairy producers keep their cattle under poor management conditions and provide little supplementary feed and health care similar to earlier reports in central highlands of Ethiopia [11].

According to the informants average daily milk yield had significant difference $(\mathrm{p}<0.05)$ between local and cross breeds. The daily milk yield of local breed was 1.06 liters and that of crossbreed was 6.49 liters. This was below the values 1.26 liters and 11.53 liters of milk/cow/day for local and cross breed respectively as reported by Ahmed, respectively [12]. The amount of milk produced per day/cow by local cows in the study was also lower than the value $2.8 \mathrm{~kg}$ milk/head/day reported for local Zebu breed by Bereda [5]. This may be due to the reason that the owners didn't give sufficient supplementary feed other than natural grazing and crop residue, like as those of cross breed owned informants. This result was also lower than the report by Seifu where average of 2 liters for local breed and 16.5 liters for cross breed indicated [13]. This may be due to management difference where in this study almost all cow owners practice extensive farming system. However, the daily milk yield of crossbred cows observed in the present study is higher than the value $5.6 \mathrm{~kg} / \mathrm{head} /$ day reported by Mukasa for crossbred cows in Arsi highlands of Ethiopia [14]. High daily milk yield observed in crossbred cows in the present study might be attributed to the high blood level or better management used in Tiyo district.

In addition, values of lactation length were recorded in months since most of the farmers didn't have records and it was difficult for them to recall the lactation length in days. Based on the informants answer lactation length had significant difference $(\mathrm{p}<0.05)$ between local and cross breeds. The lactation length of local cows was 10.29 months and that of crossbred 


\begin{tabular}{|c|c|c|}
\hline Variables & Local breed & Cross breed \\
\hline Milk selling practice & $4(2.03 \%)$ & $118(63.1 \%)$ \\
\hline Butter selling practice & $136(69.04 \%)$ & $185(98.9 \%)$ \\
\hline Cheese selling practice & $128(64.97 \%)$ & $184(98.39 \%)$ \\
\hline \multicolumn{2}{|c|}{ Reason for not selling milk (\%) } \\
\hline Lack of market & $3(1.55 \%)$ & $52(75.36 \%)$ \\
\hline Scarcity of milk & $187(96.89 \%)$ & $19(27.53 \%)$ \\
\hline Cultural restriction & 0 & \\
\hline
\end{tabular}

Table 5: Marketing practice of whole milk and milk products among respondents and associated constraints.

\begin{tabular}{|c|c|c|}
\hline Problems & Number of informants & prevalence \\
\hline Abortion & 44 & $11.46 \%$ \\
\hline Delay of first calving & 30 & $7.8 \%$ \\
\hline Long calving interval & 78 & $20.3 \%$ \\
\hline Mastitis & 38 & $9.89 \%$ \\
\hline Retained fetal membrane & 8 & $2.08 \%$ \\
\hline Uterine prolapse & 1 & $0.26 \%$ \\
\hline
\end{tabular}

Table 6: Major reproductive problems reported by informants.

cows was 16.79 months. These figures are above the national averages for lactation length of local cows i.e., 7.85 months [14] and crossbreed cows had 9.16 months by Ahmed [12]. In this study lactation length in local breed was almost the same with that of Bereda [5].

The calving interval is a period between two consecutive parturitions and should ideally be about 12 to 13 months. The calving interval (CI) for local cows was found to be 3.1 years and that of crossbred cows was 2.63 years, hence it had significant difference $(\mathrm{p}<0.05)$ between local and cross breeds. These values were longer than 2.08 years calving interval in highland local breeds and 1.28 years calving interval in crosses [14]. Short lactation length and long calving interval observed might have been attributed to the poor management conditions and poor plain nutrition of the cows in the study area. Plain nutrition is a major factor that determines the productive and reproductive performances of dairy cows [12].

During study period, most of dairy farmers who own cross breed in the districts practice the informal marketing system, where they sold their products to organization called Idget Behibret. However, whole sale of fresh milk was not a common practice especially those rearing local breed. Among different reasons, inefficient milk production (96.89\%) and lack of market (1.55\%) were the most common reasons incriminated by the informants. The proportion was higher than situation that was reported in Eastern Wollega where $21.3 \%$ of the women did not sell fresh milk mainly due to scarcity of milk, but the proportion of cultural restriction toward selling of fresh milk was dominant in Eastern Wollega [15]. In this study $63.1 \%, 98.9 \%, 98.39 \%$ of households with cross breed have milk, butter and cheese selling practice, respectively. They sell high proportion of butter and cheese than reported by Birhan [3]. Whereas, $2.03 \%, 69.4 \%$ and $64.97 \%$ of house hold who rear local breed have experience of milk, butter and cheese selling practice, respectively which was higher than that was reported by Bereda [5]. The reason for this variation was cross breed cows has genetically had the ability to produce more milk than local breed cows. Among the dairy products most commonly marketed by smallholder dairy farmers in study area were cheese and traditional butter than whole milk.

The result of current study indicated that long calving interval, abortion and mastitis found to be the major common problems in the area; followed by delay of first calving, retained fetal membrane and uterine prolapse. The prevalence of abortion in this study was higher than $1.0 \%, 2.23 \%, 5.96 \%$ and $6.3 \%$ as reported by Gashew et al., Gizaw, Berihu and Shiferaw et al. [16-19]. These results suggest that breed, geographic location, case definition and procedural differences are all source of difference in prevalence of abortion. The prevalence of RFM in this study was lower than reported with the range of $11.9 \%-24 \%$ by Gashew and Tekelye $[16,20]$. The variation in the prevalence of RFM may be attributed to variation in predisposing factors including nutritional status and management.

\section{Conclusion and Recommendation}

Milk production in Tiyo district is low; despite its great role in nutritive value and income generation. Indigenous local breed cows are dominantly owned by illiterate and elementary background than cross breed cows, which are characterized by low milk production. Improving such low milk production in local breed through AI service is severely constrained by genetic factor, lack of awareness among farmers, inadequate AI service and feed shortage. Inadequate veterinary services, shortage of land for forage production are the major problem. Marketing of dairy products is also restricted to butter and cheese for those informants rearing local breed. Milk and milk product collection center or co-operatives didn't located at different site to be accessible. Therefore, according to this study farmers are not profitable from the livestock sector, hence government and related development partners should work with the community to overcome the constraints and commercialize the sector to benefit the community.

\section{References}

1. Beriso K, Tamirat B, Feyera T (2015) Characterization of Smallholder cattle milk Production System in Aleta Chukko District, Southern Ethiopia. J Adv Dairy Res 132: 2 .

2. Gugsa G, Gebrecherkos F, Taddele H (2014) Assessment on the Availability of Potential Feed Resources in Commercial Dairy Farms in Selected District of Tigray Region, Ethiopia. Am Eurasian J Sci Res 9: 157

3. Birhan M, Teka K, Tsegaye M (2015) Constraints and Opportunities on Small scale Dairy Production and Marketing in Gondar Town Department of Animal Production and Extension, Faculty of Veterinary Medicine. University of Gondar, World Dairy and Food Science 10: 90.

4. CSA (2011) Agricultural Sample Survey Report on Livestock and Livestock characteristic (private peasant holdings). Addis Ababa, Ethiopia, pp: 9-26.

5. Bereda A, Yilma Z, Nurfeta K (2014) Dairy Production System and Constraints in Ezha District of the Gurage Zone, Southern Ethiopia. Global Veterinaria 12: 181.

6. Trushfield M (2005) Veterinary Epidemiology. 3rd edn. United Kingdom. Black Well Sciences Ltd., p: 626.

7. Asaminew T, Eyassu S (2009) Smallholder dairy production system and emergence of dairy cooperatives in Bahir Dar Zuria and Mecha Woredas, North western Ethiopia. World J Dairy Food Sci 4: 185-192.

8. Tesfaye M (2007) Characterization of cattle milk and meat production, processing and marketing system in metema district, Ethiopia. Hawassa University, Ethiopia.

9. Fisseha $M$ (2009) Studies on production and marketing systems of local breed cow in Bure district, North-West Amhara. Hawassa University, Hawassa, Ethiopia.

10. Mesfin T (1992) Overview of livestock in Ethiopia

11. Zelalem Y, Ledin I (2000) Milk production, processing, marketing and the role of milk and milk products on the small holder farms in central high lands of Ethiopia. Ethiopian Institute of Agricultural Research.

12. Ahmed M, Ehui S, Assefa Y (2004) Dairy development in Ethiopia. Washington, DC Environment and Production Technology Division, IFPRI. 
Citation: Girma D, Jerjero T, Mekuria S (2017) Community Perception on Breed Selection and Feeding Practice among Small Holder Dairy Farmers in Tiyo District, Arsi Zone, Ethiopia. J Vet Sci Technol 8: 451. doi: 10.4172/2157-7579.1000451

13. Seifu E, Doluschitz R (2014) Analysis of the dairy value chain: Challenges and opportunities for dairy development in Dire Dawa, Eastern Ethiopia. Int J Agric Policy Res 2: 224-233.

14. Mukasa $E$ (1989) A review of reproductive performance of female Bos indicus (Zebu) cattle. ILCA Monograph No. 6. Addis Ababa, Ethiopia: International Livestock Centre for Africa (ILCA).

15. Alganesh T (2002) Traditional milk and milk products handling practice and raw milk quality in Eastern Wollega. MS Thesis, Haramaya University, Harmaya, Ethiopia.

16. Gashew A, Worku F, Mulugeta SH (2011) Assessment of small holder dairy production system and their reproductive health problems in Jimma town, south western Ethiopia, Jimma university college of Agricultural and Veterinary Medicine. Int J Appl Res Vet Med 9: 84.
17. Gizaw Y, Bekana M, Takele A (2007) Major reproductive health problem in small holder dairy production in and around Nazareth town, central Ethiopia. Int J Vet Med.

18. Berihu H, Abebaw G (2009) Major reproductive health problems of dairy cows in and around Bako, west Ethiopia. Ethiopian J Anim Prod 9: 89-98.

19. Shiferaw Y, Bekana B, Tenhagen A, Kassa T (2003) Reproductive performance of cross breed dairy cows in different production system in central highlands of Ethiopia. Trop Anim Health Prod 35: 551-561.

20. Tekelye B, Kasali B, Gashew T (1992) Reproductive problems in indigenous cattle of the ministry of agriculture farms in central Ethiopia. Trop Agric 69: 247-249. 